\section{International Congress for Experimental Cytology}

THE sixth International Congress for Experimental Cytology will be held at Stockholm during July 25August 1, 1940. A preliminary programme has been arranged by the Swedish organization committee (President, Prof. John Runnström; Secretary, Dr. Sven Hörstadius ; address : Wenner-Grens Institut, Norrtullsgatan 16, Stockholm). It has been developed from the point of view of cellular physiology. The conventional distinctions between physical chemistry, biochemistry and cellular physiology have at present no sharp borders. Therefore place has been reserved for physico-chemical discussions of the behaviour of the components of protoplasm. Opportunities will, however, be provided for the arrangement of informal afternoon sessions wherein smaller groups may enjoy unrestricted discussion. Membership fee for the Congress is 25 Swedish crowns.

\section{Lady Tata Memorial Trust}

The Trustees of the Lady Tata Memorial Fund announce that, on the recommendation of the Scientific Advisory Committee, they have made the following awards for research in blood diseases with special reference to leukæmia, in the academic year beginning on October 1, 1939. Grants for research expenses: Dr. Jørgen Bichel (Aarhus, Denmark); Dr. Julius Engelbreth-Holm (Copenhagen); Dr. Maurice P. J. Guérin (Paris); Prof. Karl Jármai (Budapest); Prof. James MeIntosh (London); Prof. Eugene L. Opie and Dr. Jacob Furth (New York); and Dr. Joachim Wienbeck (Breslau). A part-time personal grant and grant for research expenses has been made to Dr. Werner Jacobson (Cambridge), and a whole-time scholarship awarded to Dr. Edoardo Storti (Pavia).

\section{The Colonial Service: Recent Appointments}

THE following appointments and promotions in the Colonial Service have been made: F. E. Reid, chemist, Institute of Medical Research, Federated Malay States; Dr. W. Rintoul, assistant analyst, Straits Settlements ; A. Huddleston, geologist, Gold Coast; L. H. Lester, veterinary officer, Uganda ; B. E. Webb, utilisation officer, Forestry Department, Tanganyika Territory; G. K. G. Campbell (agricultural officer), botanist, Nigeria; E. F. Martin (agricultural officer), senior agricultural officer, Uganda; R. O. Williams (chief horticultural officer, Palestine), deputy director of agriculture, Trinidad; W. D. MacGregor (conservator of forests, Nigeria), conservator of forests, Sierra Leone ; J. N. Oliphant (director of the Imperial Forestry Institute, Oxford, and formerly department director of forestry, Malaya), chief conservator of forests, Nigeria; Captain R. L. Creery (veterinary officer), senior veterinary officer, Kenya ; W. G. Emerson (veterinary officer), senior veterinary officer, Kenya; W. Fotheringham (veterinary officer), senior veterinary research officer, Kenya ; F. H. Geake (assistant analyst, Straits Settlements), chemist, Customs and Excise Department, Federated Malay States.

\section{Announcements}

Viscount Nuffield and Mr. John Davison Rockefeller have been elected fellows of the Royal Society in accordance with the terms of Statute 12, which provides for the election of persons who, in the opinion of the Council, "either have rendered conspicuous service to the cause of science, or are such that their election would be of signal service to the Society".

DR. W. BowIE, formerly chief of the Section of Geodesy of the U.S. Coast and Geodetic Survey, has been given the first Bowie Medal of the American Geophysical Union. The medal was established to commemorate his work for geophysical research, and will be awarded annually for outstanding achievement in related work.

A portrait of James Watt was unveiled by Sir Nigel Gresley at the Institution of Mechanical Engineers during the course of a reception held on June 9. The portrait represents Watt at fifty-seven years of age; it was painted in 1792 by Charles Frederick von Breda, and was acquired by the Institution from the family of John Rennie in 1936. During the reception, a formal announcement was made of the award of the James Watt International Medal to Mr. Henry Ford, and an address was delivered by the American Ambassador.

THE new laboratories at Mill Hill, London, N.W.7, of the Imperial Cancer Research Fund will be opened officially on June 27 by Lord Halifax, president of the Fund. Sir Frederick Gowland Hopkins will deliver an address on "Scientific Aspects of Cancer Research".

ThE ninth General Conference of Weights and Measures will meet in Paris and Sèvres early in October.

As International Exhibition against Air Attack will be held at Brussels on July 8-29 at the same time as the second International Salon of Aeronautics. Further information can be obtained from La ligue de Protection Aerienne, 182 rue de la Loi, Brussels.

THE sixth Pacific Science Congress will be held at Berkeley, Stanford and San Franciseo during July 24August 12, under the auspices of the U.S. National Research Council. Programmes and further information can be obtained from Dr. Roy. E. Clausen, Room 205, Hilgard Hall, University of California, Berkeley, California.

We are informed by Prof. C. Daryll Forde that his work on the tribal customs in the Obubra Division of Southern Nigeria, referred to in NATURE of May 13, p. 815, was carried out while he held a Leverhulme Research Fellowship for field work in Nigeria, and not, as stated in Africa, a Rockefeller research fellowship of the International Institute of African Languages and Cultures. 